\title{
Movimentos nostálgicos no atual cenário musical: consumo de experiências e experiências de consumo no último show da turnê 'Nossa História', de Sandy e Junior ${ }^{1}$
}

Julia Rafaela Bruce de Oliveira Ferreira e Silva

Pontifícia Universidade Católica do Rio de Janeiro - PUC-Rio

Departamento de Comunicação Social - Bacharelado em Jornalismo

\section{Resumo}

Este artigo busca analisar o fenômeno de revival da dupla pop nacional Sandy e Junior, por meio da breve turnê de retorno "Nossa História", em 2019. O objeto de estudo foi o comportamento dos fãs millennials presentes no último show do Parque Olímpico, procurando compreender o evento não somente como um produto cultural ou midiático, mas como um espaço de revisitação e de ressignificação de memórias. Para a análise, foram realizados grupos focais com fãs de quatro regiões do Brasil para entender o consumo de experiências e as experiências de consumo no dia do evento. A fundamentação teórica reuniu os temas: nostalgia, marketing de nostalgia e de experiência, consumo na sociedade hipermoderna e os conceitos de consumo de experiências e experiências de consumo.

Palavras-chave: Comportamento do consumidor; Experiência; Nostalgia; Memória; Marketing de experiência.

\section{Introdução}

A efervescência do retorno ao passado na música, por meio das turnês de celebração da carreira de um artista, dos retornos de grupos dos anos 1990 e 2000 ou das vendas de vinis, por exemplo, está fazendo parte da rotina de muitos fãs. Nesse cenário, entram as estratégias do marketing de experiência em produtos que têm apelado para a nostalgia na forma de divulgar, vender e, acima de tudo, proporcionar experiências reais de uma marca. A partir deste contexto, o presente trabalho tem como proposta analisar o consumo de experiências e as experiências de consumo proporcionadas pelo último show de Sandy e Junior da turnê "Nossa História", buscando compreender como o revival atingiu o público presente em espaços de memórias, levando em consideração o processo do marketing nostálgico e de experiência durante a apresentação e refletindo sobre os modos de consumo contemporâneo.

\footnotetext{
${ }^{1}$ Artigo derivado de monografia de graduação em Jornalismo, orientada pela professora Luciana Azevedo Pereira e entregue em dezembro de 2020.
} 
O recorte de público é referente aos millennials ou Geração $Y$, jovens nascidos no "início dos anos 1980 até os anos 2000" (CRUZ, 2018, p. 14), visto que cresceram com os irmãos, e é uma geração que prioriza mais a experiência, o investimento em si mesma e menos bens ${ }^{2}$. Diante desse cenário, foram reunidas as seguintes teorias: nostalgia (BOTELHO e PLUTARCO, 2012; FERRAZ e SANTA CRUZ, 2018; HUYSSEN, 2000; LOPES, 2015; NIEMEYER, 2018), marketing de nostalgia e de experiência (BAKER e KENNEDY, 1994; COSTA, MELLO e PESSÔA, 2017; KOTLER, 2010; KOTLER e ARMSTRONG, 2015; MORAIS e GOMES, 2015), consumo na hipermodernidade (LIPOVETSKY, 2004; 2007) e consumo de experiências e experiências de consumo (MCCRACKEN, 2007; PEREIRA, ROCHA e SICILIANO, 2015; PEREZ, 2020).

Para identificar e compreender tendências e comportamentos de um grupo específico, foi utilizada a metodologia Grupo Focal ou Grupos de Foco, modelo de pesquisa qualitativa e que exclui a possibilidade de buscas ligadas a deduções ou generalizações. O Grupo Focal compreende uma entrevista coletiva mediada pelo pesquisador por meio de um roteiro de perguntas e, em seguida, a etapa de avaliação (BELCZAK, 2015). Neste trabalho, cada grupo de foco foi dividido em três momentos: a expectativa e preparação para o evento; as experiências durante o show; e uma pergunta final sobre o que o revival de Sandy e Junior significou para os fãs.

A busca pelos participantes foi realizada em dois grupos de fãs no Facebook "SANDY E JUNIOR O GRUPO" (21 mil membros) e "Sandy in Rio" (1,8 membros) formado por uma média de fãs entre 25 e 34 anos, de acordo com dados fornecidos pelos administradores. Após convite e interesse em participar, foram criados três grupos para definição de datas, lembretes e pedidos para separação de recordações relacionadas ao último show.

Os três Grupos Focais foram realizados de forma virtual no período de 11 a 22 de novembro de 2020 com um total de 17 participantes ( 25 a 36 anos). Todos tiveram duração de 2 horas a 2 horas 30 e foram gravados com as devidas autorizações de imagem e voz:

- Informante A: 27 anos, mora no Méier (subúrbio do Rio de Janeiro), trabalha com administração, é fã de Sandy e Junior desde criança, e na "Nossa História" também foi ao show em Porto Alegre (RS).

${ }^{2}$ OLIVEIRA, Joana. Sandy \& Junior, produto nostálgico sob medida para os 'millennial'. El País, 22/03/2019. Disponível em: https://brasil.elpais.com/brasil/2019/03/20/cultura/1553112221 437120.html Acessado em: 17/03/2020 
- Informante B: 27, mora em Guarulhos (SP), é jornalista, fã de Sandy e Junior desde 1997, fez parte do fã-clube "A Gente Dá Certo" e "DNA". Foi em todos os quatro shows em São Paulo.

- Informante C: 24, mora no Centro do Rio de Janeiro (RJ), é intérprete de libras, costuma dizer que é fã da dupla desde o ventre da sua mãe. Foi ao show de data extra do Rio de Janeiro. Fez parte de fã-clubes como "Central", "DNA" e continua no "Simplesmente Sandy".

- Informante D: 36, mora em Grajaú (BH), é formada em Direito e é fã da dupla desde os 5 anos (época em que conheceu os artistas durante um concurso no qual imitou Sandy apresentando "Maria Chiquinha").

- Informante E: 32, Rio de Janeiro (RJ), é assistente de departamento pessoal, fã de Sandy e Junior desde 25/12/1998 e foi em todos os shows do Rio de Janeiro, incluindo o pacote Gold na última apresentação.

- Informante F: 32, é de Cuiabá (MS), fã desde os 7, e foi ao show em Fortaleza (CE).

- Informante G: 27, Rio de Janeiro (RJ), atua na área de Pedagogia, e é fã da dupla desde os 3. Chegou a comprar para São Paulo, mas vendeu quando soube do show de encerramento.

- Informante H: 28, de Curitiba (PR), é jornalista, fã de Sandy e Junior desde os 12, foi aos shows de São Paulo (SP), Curitiba (PR) e Belém (PA) e participou da coletiva de imprensa da turnê.

- Informante I: 28, estuda Medicina no Paraguai, é fã da dupla desde criança, mas devido às dificuldades de custo e de deslocamento por ser de Itaperuna (interior do RJ) nunca conseguiu ir a um show da dupla.

- Informante J: 25, de Corumbá (MS), tem formação em Letras, também não chegou a ir a um show quando menor, mas ganhou um ingresso para a "Nossa História" de Dia dos Namorados.

- Informante K:23, com formação também em Letras, é de Fortaleza (CE), fã desde criança e foi influenciado pelo irmão mais velho.

- Informante L: 33, morava em Niterói (RJ) na época da turnê. É mestre em Direito Institucional, fã da dupla desde 1997, foi ao segundo show do Rio de Janeiro.

- Informante M:33, mora em Jacarepaguá (Zona Oeste do Rio de Janeiro), atua com Publicidade, é fã da dupla desde os 11, foi aos dois primeiros do Rio de Janeiro, de Belo Horizonte (MG), Porto Alegre (RS), no terceiro de São Paulo e comprou o pacote "VIP Diamante" para o último show.

- Informante N:28, mora em Pechincha (Zona Oeste do Rio de Janeiro), é fã há 21 anos e nunca foi ao show da dupla antes, mas durante a "Nossa História" foi aos shows do Rio Janeiro, dois de São Paulo e um no Paraná. 
- Informante 0:31, mora na Tijuca (Zona Norte do Rio de Janeiro), docente de Química, é fã da dupla desde 1997, e na "Nossa História" foi em dois shows no Rio de Janeiro e dois em São Paulo.

- Informante P:36, nasceu em Fortaleza (CE), trabalha com Produção Cultural, se declarou fã da dupla aos 14 e foi ao show de Brasília (incluindo pacote "VIP Gold").

- Informante Q: 37, mora em Foz do Iguaçu (PR), atua como historiadora ambiental e é fã da dupla desde pequena.

- Informante R:28, mora em Cachoeiras de Macacu (interior do RJ), trabalha na área pública, é fã da dupla desde os 7 e nunca chegou a ir antes em um show da dupla.

\section{Sandy e Junior}

Os irmãos Sandy Leah Lima (38) e Durval de Lima Junior(37) são naturais de Campinas (SP) e filhos do cantor Xororó e da empresária Noely Lima ${ }^{3}$. O início da carreira ocorreu na primeira aparição em rede nacional por meio do programa Som Brasil, da Rede Globo, em 29/05/1989, no qual Sandy (6) e Junior (5) cantaram "Maria Chiquinha". Até 1992, os discos faziam parte do universo sertanejo, gênero musical que dominava as paradas do repertório nacional, mas, a partir de 1993, o gênero pop permaneceu nos CDs. Em 17 anos de carreira, os irmãos produziram 16 álbuns - com 15 milhões de cópias vendidas ${ }^{4}$ - e também fizeram sucesso internacional em países da América Latina, Estados Unidos e Europa, conforme dados da exposição Sandy e Junior Experience $(2019)^{5}$. A trajetória ainda contou com programas, filmes e novelas na televisão, comoo seriado "Sandy e Junior"(1999-2002) ${ }^{6}$ e o filme "Acquaria" (2003).

A dupla também movimentou o mercado publicitário na época por meio da venda de cosméticos a equipamentos eletrônicos e "mais de 300 produtos foram licenciados com a marca Sandy \& Junior, avaliada em R\$60 milhões entre as duas décadas [1990 a 2000]"(LETHBRIDGE, 2005 citado por MORAIS, 2019, p. 3). Entre os maiores shows, estão a turnê "Eu Acho Que Pirei" (1998), com mais de 8,5 milhões de ingressos vendidos; o show no

\footnotetext{
${ }^{3}$ SANDY e Junior. Dicionário Cravo Albin da Música Popular Brasileira. Disponível em: http://dicionariompb.com.br/sandy-e-junior/dados-artisticos Acessado em: 17/05/2020

${ }^{4}$ SANDY E JUNIOR: UMA, carreira de 15 milhões de discos vendidos. Jornal O Globo, 17/04/2007. Disponível em: https://oglobo.globo.com/cultura/sandy-junior-uma-carreira-de-15-milhoes-de-discos-vendidos-4196452 Acessado em: $14 / 06 / 2020$

${ }^{5}$ NOGUEIRA, Renata. Sandy e Junior Experience: veja os shoppings que ainda vão receber a mostra, UOL, 02/08/2019. Disponível em: https://entretenimento.uol.com.br/noticias/redacao/2019/08/02/sandy-e-juniorexperience-veja-todos-os-shoppings-que-vao-receber-a-mostra.htm Acessado em: 24/10/2020

${ }^{6}$ ZORZI, André Carlos. Seriado 'Sandy e Junior' completa 20 anos; veja como está o elenco e relembre a história. 0 Estado de S. Paulo, 11/04/2019. Disponível em https://emais.estadao.com.br/noticias/tv, seriado-sandy-e-juniorcompleta-20-anos-veja-como-esta-o-elenco-e-relembre-a-historia,70002784245 Acessado em: 04/04/2020
} 
palco principal da terceira edição do Rock in Rio (2001); além do show no Maracanã (2002) para mais de 70 mil pessoas ${ }^{7}$, sendo os primeiros artistas brasileiros a lotarem o estádio ${ }^{8}$.

\section{Turnê "Nossa História"}

Entre julho e novembro em 2019, foi realizada a turnê "Nossa História" em comemoração dos 30 anos de carreira dos irmãos, após hiato de 12 anos. Os artistas passaram por todas as regiões do país e ainda estiveram em New York (EUA) - na arena Barclays Center, os primeiros brasileiros a realizarem um show no local $^{9}$ - e em Lisboa (Portugal) - na Altice Arena, palco que recebeu artistas como Madonna e Iron Maiden ${ }^{10}$.

No total, foram 18 shows, e a última apresentação teve a presença de mais de 100 mil pessoas lotando o Parque Olímpico - Cidade do Rock, no Rio de Janeiro (RJ). A turnê foi classificada como a segunda mais lucrativa em bilheteria do mundo, ficando atrás da turnê do cantor inglês Elton John e arrecadando cerca de US\$2,26 milhões. ${ }^{11}$ Antes da venda dos ingressos para o último show, cerca de 500 mil haviam sido vendidos somente no Brasil e "nunca na história uma turnê atingiu vendagens tão significativas"12. A "Nossa História" foi considerada a maior turnê da música brasileira e "com a venda de ingressos, faturou exatamente $\mathrm{R} \$ 120.041 .018$ milhões $^{13}$.

\footnotetext{
7OS TRÊS shows mais históricos da carreira de Sandy \& Junior. Papel Pop, 01/08/2020. Disponível em: https://www.papelpop.com/2019/08/os-tres-shows-mais-historicos-da-carreira-de-sandy-junior/ Acessado em: 04/04/2020

8SANDY E JUNIOR: UMA carreira de 15 milhões de discos vendidos. Jornal O Globo, 17/04/2007. Disponível em: https://oglobo.globo.com/cultura/sandy-junior-uma-carreira-de-15-milhoes-de-discos-vendidos-4196452 Acessado em: $14 / 06 / 2020$

${ }^{9}$ QUEIROZ, Samira. Sandy \& Junior lota arena durante show em Nova York. Quem, 02/10/2019. Disponível em: https://revistaquem.globo.com/sandy-e-junior/noticia/2019/10/sandy-junior-lotam-arena-durante-show-em-novayork.html Acessado em: 11/10/2020

${ }^{10}$ SARZI, Lucas. Com segundo show internacional, Sandy e Junior entram na reta final de turnê comemorativa.

Tribuna, 06/10/2019. Disponível em: https://www.tribunapr.com.br/mais-pop/com-segundo-show-internacionalsandy-e-junior-entram-na-reta-final-de-turne-comemorativa/ Acessado em: 11/10/2020

${ }^{11}$ TURNÊ de Sandy e Junior, 'Nossa História' é a segunda mais lucrativa do mundo em 2019. F5 - Folha de S. Paulo, 06/12/2019. Disponível em: https://f5.folha.uol.com.br/musica/2019/12/turne-de-sandy-e-junior-nossa-historia-e-asegunda-mais-lucrativa-do-mundo-em-2019.shtml Acessado em: 14/03/2020

12 FILHO, Eduardo; MARTINS, Sérgio. Como a volta de Sandy \& Junior se tornou a maior turnê da história do país. Veja, 11/10/2019. Disponível em: https://veja.abril.com.br/entretenimento/como-a-volta-de-sandy-junior-se-tornoua-maior-turne-da-historia/ Acessado em: 13/06/2020

${ }^{13}$ Turnê de Sandy e Junior arrecada mais de $\mathrm{R} \$ 120$ milhões e já é a maior da história no Brasil. EXTRA, 25/11/2019.Disponível em: https://extra.globo.com/famosos/turne-de-sandy-junior-arrecada-mais-de-120-milhoesja-a-maior-da-historia-no-brasil-24098526.html Acessado em: 17/10/2020
} 


\section{4. Último show da turnê "Nossa História}

A última apresentação no Parque Olímpico não fazia parte do calendário previsto em março de 2019. A abertura ficou por conta do trio de irmãos Melime, o encerramento ficou com o DJ Santti mais o Trio Elétrico Samby\& Junior ${ }^{14}$. Em 15 de agosto, a venda foi aberta ao público geral e, no dia 31 de outubro, a produtora Live Nation confirmou a venda de todos os 100 mil ingressos. Os preços variaram entre $\mathrm{R} \$ 290$ e $\mathrm{R} \$ 640$, e parte do valor arrecadado foi revertido em doações para projetos assistenciais ${ }^{15}$.

Uma das diferenças deste evento para os outros da turnê foi a inclusão de um segundo palco para a parte acústica. Segundo os organizadores, o palco principal era maior que o usado pelo Rock in Rio ${ }^{16}$. Com fogos de artifício no início e ao final da apresentação, canhões de papel e fitas, além de bolas coloridas pela plateia, os irmãos finalizaram o último show da mesma forma que fizeram no último show da carreira, em 2007: com um abraço e ajoelhados no chão, mas agora para um público de mais de 100 mil pessoas ${ }^{17}$. Durante o show, Sandy lembrou: "a gente cantou no Rock in Rio a apenas 18 anos atrás". E Junior complementou: "e agora a gente está com um Rock in Rio nosso"18.

\subsection{A nostalgia no show}

Pela etimologia, a palavra "nostalgia", do grego"nostos", significa retornar ao lar e "algos" a tristeza, perda ou dor - ligada, antes, somente a sentimentos e sensações negativas (BOTELHO e PLUTARCO, 2012). Mas estudos sobre o movimento de apropriação nostálgica reconhecem a necessidade de analisá-la como "um fenômeno integrado às nossas práticas socioculturais contemporâneas" (FERRAZ e SANTA CRUZ, 2018, p. 7) e pode ser ligado aos tempos presente e futuro sustentando sua pluralidade de formas, sentidos e significados. Em outras palavras, refere-se a uma memória de tempos e locais que não voltam mais; ao desejo

\footnotetext{
${ }^{14}$ ALMEIDA, Pauline. Último show de Sandy e Junior contará com abertura e encerramento. UOL, 04/11/2019. Disponível em: https://entretenimento.uol.com.br/noticias/redacao/2019/11/04/ultimo-show-de-sandy-e-juniorcontara-com-abertura-e-encerramento.htm Acessado em: 11/10/2020

${ }^{15}$ SANDY E JUNIOR ENCERRAM e Junior encerram a turnê 'Nossa história' no Rio com ingressos esgotados. EXTRA, 31/10/2020. Disponível em: https://extra.globo.com/sandy-e-junior/sandy-junior-encerram-turne-nossa-historia-norio-com-ingressos-esgotados-24053760.html Acessado em: 15/10/2020

${ }^{16}$ SARZI, Lucas. Com 100 mil pessoas, Sandy e Junior encerram turnê Nossa História no Rio de Janeiro com chave de ouro. Tribuna, 09/11/2019. Disponível em: https://www.tribunapr.com.br/mais-pop/com-100-mil-pessoas-sandy-ejunior-encerram-turne-nossa-historia/ Acessado em: 11/10/2020

${ }^{17}$ SARZI, Lucas. Com 100 mil pessoas, Sandy e Junior encerram turnê Nossa História no Rio de Janeiro com chave de ouro. Tribuna, 09/11/2019. Disponível em: https://www.tribunapr.com.br/mais-pop/com-100-mil-pessoas-sandy-ejunior-encerram-turne-nossa-historia/ Acessado em: 11/10/2020

${ }^{18}$ NUNES, Caian. Sandy \& Junior encerram a turnê "Nossa História" com público de 100 mil pessoas: "a gente está com um Rock in Rio nosso". Portal POPline, 10/11/2019. Disponível em: https://portalpopline.com.br/sandy-juniorencerram-a-turne-nossa-historia-com-publico-de-100-mil-pessoas-a-gente-esta-com-um-rock-in-rio-nosso/ Acessado em: $11 / 10 / 2020$
} 
de um retorno ou arrependimento a um tempoque não chegou a ser experimentado pela pessoa ou até por um futuro que não chegará (NIEMEYER, 2018, p. 29).

No campo geracional, as experiências desencadeadas pela nostalgia podem ser associadas aos momentos da própria juventude, sendo reconhecida como uma "memória coletiva ou memória de gerações" (HOLBROOK e SCHINDLER, 2003, citado por BOTELHO e PLUTARCO, 2012, p. 2), tornando-se uma escolha pelas experiências ligadas a pessoas, lugares ou objetos que eram mais populares na sua infância ou juventude. Ao falar sobre momentos em que foram apresentados o teaser da turnê, em uma publicação nos stories dos irmãos em 31 de janeiro de 2019, com a pergunta "Vamos conversar em março?, e a publicação do anúncio oficial da turnê, os informantes já dão indícios da nostalgia.

Várias amigas minhas me mandaram antes de eu ver nos stories, sempre cantamos Sandy e Junior no karaokê da Feira de São Cristóvão. Falei: "Não vamos surtar, porque se for alguma coisa nada a ver vamos desesperar à toa". Foi exatamente o contrário, ficamos desesperadas ao longo do ano inteiro, mas foi muito mais do que a gente esperava. Informante A

Eu fiquei em choque e falei: "Será que é show, será que é tipo um remake do seriado novamente?" Também pensei no "Acústico MTV"! Se for show vai ser uma oportunidade, porque quando eu era criança não pudeir e tive um surto! Em relação ao post da turnê, achava que não ia conseguir ir, porque moro muito longe de qualquer lugar que tinha show, impossível! Foi aquela euforia! Informante J

Minha irmã é seis anos mais nova que eu e, desde criança, era minha dupla. Quando vi os stories, mandei pra ela de primeiro e disse: "O Junior vai entrar em ação!". Ela não pôde ir, mas dei o ingresso pra minha outra irmã que aprendeu a gostar de Sandy e Junior graças a gente ficar insistindo tanto, ouvindo as músicas. Dividimos Spotify e ela ouve todas. E tudo o que meu irmão de 11 anos vê sobre eles me mostra. Informante $\mathrm{F}$

O vídeo de introdução do show começava com um áudio dos irmãos chamando um e outro e, depois, um misto de imagens com um resumo da trajetória dos 17 anos foram expostos rapidamente durante dois minutos.

Me veio exatamente a imagem do meu pai que ia comigo aos shows, à loja de discos comigo, tanto que quando cheguei do show peguei esse aqui [mostra o CD "Sandy \& Junior", de 2001] que foi um dos primeiros que ele me deu e chorei abraçado ao disco até quase no outro dia de manhã. Informante $\mathrm{K}$

É muito emocionante, porque de fato as músicas são trajetória, é toda a história de mim criança. Minha vizinha é minha amiga há 26 anos. Eu 
era o Junior, ela era a Sandy, e a gente fazia show para nossas famílias. Informante $\mathrm{G}$

Pra fã, tem um outro significado, não é só nostálgico, é muito maior, porque passamos tanto anos sem ver a dupla nos palcos. É completamente diferente viver isso agora, de uma forma muito mais clara e lúcida, porque a gente era muito criança e não fazia ideia do que eles significavam nem tinha ideia do tamanho que eles eram. Informante $\mathrm{M}$

A relação entre o boom da memória (HUYSSEN, 2014, citado por BORGES, LAGE e LEAL, 2018)e o da nostalgia é "qualquer narrativa de reconstrução memorialística é automaticamente 'nostálgica'" (NIEMEYER, 2014, citado por BORGES, LAGE e LEAL, 2018, p. 51) e a segunda não precisa ser somente considerada uma expressão de sentimentos, mas também, uma ação. Seus efeitos nos mostram que a sociedade precisa de uma "ancoragem temporal" nesse entrecruzamento entre passado, presente e até futuro (HUYSSEN, 2000, p. 36), e o show foi identificado como um espaço nostálgico para narrativas de reconstrução de memórias e produções de sentidos, novas lembranças e ações:

Eu comecei a procurar meus CDs. Eles [a Universal Music] fizeram uma playlist das músicas do show e comecei a ouvir muito, fiquei insuportável. Na época, meu irmão foi fã junto comigo. Comecei a seguir a página de fã-clube para acompanhar as notícias, é muito louco! Parece realmente que virou uma chave e você volta a ser surtado de fã! Informante I

Fizemos questão de fazer todas as coreografias no show! Informante $O$

É importante destacar que quando os objetos mais comuns durante o período da infância ou juventude estão associados àquela experiência, a nostalgia se torna a protagonista (HOLBROOK e SCHINDLER, 2003, citados por BOTELHO e PLUTARCO), e produtos de comunicação nostálgicos, como o vídeo de introdução apresentado, geram no espectador reações diversas atreladas ao resgate de memórias. Os estímulos proporcionados por essa forma de comunicação provocaram a "nostalgia real" (BAKER e KENNEDY, 1994, citadas por LOPES, 2015, p. 31) no público. Essa nostalgia é ligada ao desejo por um passado já vivido por aquela pessoa e um dos fatores que reforçam isso é quando elas "buscam estímulos que possam transformar aquela recordação em uma experiência sagrada, como exemplo, músicas, fotos, entre outros estímulos, que auxiliaram a simbolizar a autenticidade da experiência". (LOPES, 2015, p. 31).

Quando eu vi a primeira mensagem de Sandy e Junior no ar, que ia ter turnê, falei: "Vou realizar meu sonho!" e vou todo caracterizado de S\&J como eu ia pra escola. Lembrei da minha mochilinha de criança e falei: 
"Não, eu tenho que ir com ela porque é minha companheira de infância." Minha mãe me deu de presente de nove anos. Informante C

Quando era criança, morava no interior, minha mãe fazia doutorado em Belo Horizonte e pedia para ela trazer roupas da Sandy de presente. Eu não tinha celular, mas mostrava para ela na televisão. Ela trazia exatamente a roupa que eu queria. Vi no telão [do vídeo de introdução] três figurinos que eu tinha. Informante $D$

\subsection{Satisfações proporcionadas pelo marketing de nostalgia e de experiência}

"A propaganda faz parte de um mix de marketing" (DRUCKER, 2012 citado por KOTLER e ARMSTRONG, 2015, p. 4), é como um bônus que ativa diversas reações ou gatilhos no consumidor. Em específico, o Marketing 3.0 mostra que os valores atrelados aos produtos são fundamentais ao consumir determinada marca. Os consumidores também são vistos como seres humanos "com mente, coração e espírito" (KOTLER, 2010, p. 4) buscando satisfação funcional, emocional e espiritual nos produtos escolhidos. A partir desse cenário, a humanização das marcas passou a ser referência para as empresas, em que a promoção de experiências é mais importante do que a venda de produtos (GOBÉ, 2002 citado por MORAIS e GOMES, 2015).

Gilles Lipovetsky (2007) define a nossa sociedade como "hipermoderna", em que nossas motivações pessoais influenciam as decisões de compra, pois "queremos objetos 'para viver"' cuja satisfação emocional é posta em primeiro lugar. Dessa forma, o consumo passa a ter também uma "função identitária", por ser ligado ao ambiente individual e familiar que cerca o indivíduo, fazendo com que ele tenha uma personalidade determinada e saiba defini-lo (LIPOVETSKY, 2007, p. 25-28).

É nesse contexto que entram os compostos do marketing nostálgico "alegoria, arcadia, aura e antinomia". "Alegoria" é a narrativa simbólica usada e influenciada pela publicidade; "arcadia" significa utopia a grupos do passado; "aura" é o que a essência da marca representa para os consumidores; e a"antinomia" reflete na relação entre os tempos passado e presente, cujos avanços tecnológicos e o tempo acelerado são as causas de desejo do retorno ao passado (BROWNet al, 2003 citado por COSTA, MELLO e PESSÔA, 2017). Assim, pode-se relacionar com a motivação da compra dos ingressos para os shows da turnê e durante o momento em que foi apresentado o vídeo de simulação da conversa entre os atores do seriado "Sandy e Junior" que mostrava os personagens se reencontrando em um aplicativo de conversa relembrando a época dos bastidores, com áudios, GIFs e figurinhas compartilhadas, identificados abaixo respectivamente: 
O ápice do show para mim foi esse momento do seriado, porque como eu não quis ver nada, ser surpreendida, não sabia que ia ter aquilo. Eu gravava o seriado. Lembrei da primeira vez que tive contato com eles em 1991, minha vizinha de cima tinha o LP e dava para ouvir da janela. Eu não via, não curtia ainda, mas foi com 14 anos que eu dei um "clickzinho". Informante $\mathrm{P}$

Eu voltei a ser criança e acho muito bom. A gente tem que ser "brincante", feliz e ter sua criança sempre ativa dentro de você, porque de fato é o que faz a gente se movimentar, ser alegre e não ser aquele adulto chato. Ser adulto é muito cansativo, é muita preocupação, então estar ali trabalhando, por exemplo, e escutando Sandy e Junior ativa uma memória dentro de você que tá te movimentando. Informante $\mathrm{G}$

Quando abriu [a venda] para o Parque Olímpico foi uma motivação, amigas minhas de muitos anos se animando. A proporção que aquele show tomou foi tão grande que todo mundo tem que ir. Eu nunca tinha ido ao show de Sandy e Junior, era muito pequena e lembro (esse é meu maior arrependimento da vida) que a minha madrinha tinha me oferecido pra ir ao show deles no Maracanã, mas tinha medo de tumulto. Informante $A$

Foi legal relembrar hoje, ter essa sensação que a última vez que tive foi vendo o documentário, assisti só uma vez e não consegui assistir de novo, pela questão de ficar muito nostálgica. É muito bonito! É muito incrível o que eles fazem, o que eles eram e ainda estão com a gente, um bando de velho adulto, trabalhador e chorando! Informante $\mathrm{G}$

As reações dos fãs ao conseguirem os ingressos refletem no valor que a marca Sandy \& Junior tem para cada um e o quanto as experiências de compra garantiram "satisfações funcionais, emocionais e espirituais" (KOTLER, 2010, p. 4):

Tava na hora da escola do meu filho e levei o menino de mochila pra fila, mas não consegui comprar. Fiquei arrasada! Passou um tempo, foi meu aniversário de casamento e meu marido me deu de presente o ingresso do Rio [do último show] e nem acreditei! Informante D

Pra esse eu organizei uma força tarefa. Tinha umas 30 pessoas prontas para comprar o ingresso comigo. Todas minhas amigas combinaram de ir juntas, mas uma não podia ir, tava sem dinheiro e demos de presente de aniversário. Ela ficou realizadíssima porque nunca tinha ido ao show. Informante $A$

Na época não comprei o pacote Gold porque tava pagando ingresso de agosto, mas quando resolvi comprar, simplesmente sumiu do site. Mandei e-mail pra Ingresso Rápido, entrei em contato com Deus e o mundo, só não pedi pro Papa vir do Vaticano pra cá porque não tinha como. Mas num dia saindo pro trabalho, várias ligações no meu telefone de duas amigas: "O Gold!", sentei no lobby do prédio do trabalho, comprei o Gold ali mesmo e consegui minha grade no último show. Informante $\mathrm{E}$ 


\subsection{Os diversos consumos experienciais}

O consumo hoje tem um significado ambíguo: ao mesmo tempo que ele é um ato também é considerado um processo. Primeiro, porque tudo o que é consumado tem seu término, por outro lado, para uma finalidade ser atingida, existe um processo anterior, deixando de lado o limite de adquirir algo (PEREZ, 2020). Dessa maneira, é necessário olhar para as diferenças entre as noções de consumo de experiências e experiências de consumo que estão em volta.

O primeiro é uma prática de consumo ligada ao pessoal, ao particular. Um consumidor que está imerso em um espaço cuja memória é reativada, como em um show, em que ambientes, objetos do mundo real acabam sendo ressignificados, é característica do consumo de experiências (PEREIRA, ROCHA e SICILIANO, 2015). Já as imaginações, sensações e emoções presentes no processo de retorno do consumidor, isto é, nas experiências de consumo, tornam-se mais ativas quando um determinado espaço oferece essa imersão (PEREIRA, ROCHA e SICILIANO, 2015, p. 15). Em suma, a noção de experiências de consumo é ligada ao processo de troca do consumidor. Já o consumo de experiências depende de algumas intenções, como um espaço que foi preparado para ele viver [ou reviver] situações - físico ou on-line - e pago para usufruir da experiência. Pode depender também da própria narrativa pensada pela criação de um evento, se faz jus ou não àquela trajetória original (PEREIRA, ROCHA e SICILIANO, 2015).

Fui com a bandeira amarrada nas costas, com faixas amaradas nos pulsos e penduradas na calça, virei uma alegoria praticamente. Informante B

Quando começou "VamoPulá" ouvi um barulho forte e falei: "Gente, tá vindo a bola". Quando olhei pra trás, ela veio certinho na testa e agarrei ela. Fiquei o final do show todinho com o braço agarrado nela e depois esvaziei. Informante $\mathrm{C}$

Como me mudei para Portugal, eu trouxe o meu copo e o crachá do "Diamante" que tá pendurado na porta. Eu vou mudar de país, mas vou levar junto, faz parte de mim, da minha história, de quem eu sou e me ajudariam a ficar aqui. InformanteL

"Inesquecível" foi o boom do show pra mim, foi a hora que a gente consegue realmente resgatar as memórias da infância. "Vamo Pulá" eu já não tinha mais pernas pra pular e eu tava lá naquela vibe, pulando pra aproveitar o máximo que eu podia. Informante $\mathrm{R}$

Os objetos adquiridos no último show são, com frequência, usados pelos participantes nas suas rotinas, o que reforça a construção de uma personalidade, em referência ao novo modelo de "rituais de consumo" a partir de McCracken (2007)- que defende o processo de 
transferência de significados culturais como rituais, sejam de posse, troca, cuidados pessoais ou desapropriação, tendo em vista a trajetória daquele fenômeno. Perez (2020) afirma que o uso de certos objetos, marcas e serviços no cotidiano e a apropriação que se faz de cada um deles influencia em uma compreensão melhor de cada indivíduo.

Eu tirei o cordão do crachá do jornal e passei a usar o cordão da turnê. Esses dias fui fazer matéria policial com o cordão de Sandy e Junior e não tô nem aí. Informante $\mathrm{H}$

Já ganhei clientes no trabalho por conta dessa blusa [escrito "Dig-DigJoy"]. A pessoa estava marcada com outro funcionário para atendê-la, quando entrou, tinham dez corretores de imóveis, me viu com a blusa e perguntou: "Você foi ao show de Sandy e Junior? Eu também sou fã deles e fui". Ela sentou na minha frente, atendi e vendi o apartamento. Informante $\mathrm{K}$

Para complementar a ideia acima, os informantes foram questionados sobre a imagem dos dois triângulos, marca da turnê "Nossa História". Alguns chegaram a tatuar a marca ou sentiram vontade de fazer, ilustrando a teoria sobre o "ritual de reuso", que se caracteriza pelo armazenamento "ampliando sua vitalidade no tempo" (PEREZ, 2020, p. 69). Em outras palavras, eles quiseram guardar não somente a lembrança da turnê, mas ressignificaram o símbolo de acordo com o valor para cada um:

Eu falo que é união do Brasil todo, porque a maioria dos fãs veio. A Sandy apareceu agora no clipe "Tempo" e tatuou nas costas esse símbolo. Mesmo que não possa ter uma comemoração daqui a 60 anos da dupla, a gente vai estar sempre ligado a eles e eles à gente. Informante $\mathrm{C}$

Após a coletiva do retorno, eu tenho uma amiga [que estava junto] que me chamou pra fazer a tatuagem dos triângulos. Eu conheci ela indo para o último show em 2007, sou padrinho de casamento, e pra mim deu um novo significado interno desse sentido de amizade, de irmãos. Informante $\mathrm{H}$

Eu e minha irmã já queríamos fazer uma tatuagem juntas, só que a gente não sabia qual. Quando estreou a turnê, começamos a discutir sobre o que o símbolo significava antes de eles falarem. Temos um outro irmão também, forma um triângulo e, assim, tatuamos. Informante $\mathrm{O}$

Outros rituais propostos por Perez (2020) são os "rituais de busca", que é a pesquisa em comunidades de fãs da marca, nas redes sociais do artista, "em conversas informais ou outras fontes de informação"; os "rituais de compra" que representam o "momento da compra presencial ou e-commerce; experiência; serviços adicionais" inclusos nela; os "rituais de uso", que indicam a situação, o momento do uso mais o "significado do produto durante o uso"; os 
"rituais de posse", que significa "falar sobre, personalizar, fotografar, postar; colecionar" (PEREZ, 2020, p. 72); os "rituais de ressignificação", que indicam a indução de novos processos de consumo a partir da forma como consumimos, "fazendo circular sentidos" (PEREZ, 2020, p. 71). Esses rituais são exemplificados nos comentários dos fãs abaixo, respectivamente:

Eu lembro que entrei em contato com todas as pessoas que podia e não podia, pra poder perguntar o que achavam [sobre os primeiros stories publicados em janeiro de 2019]. Informante B

Primeira experiência Sandy e Junior foi no Parque Olímpico, e a experiência de compra foi uma loucura. Eu estava trabalhando, tinha conseguido colocar o ingresso na cesta, mas deu problema no cartão. Eu ligava perguntando: "Por que não consigo comprar?" e não consegui naquele dia. Informante $R$

Eu fiquei ainda um bom pedaço, fui pro bloco sambando, bebendo minha cerveja, linda, bela, mas fiquei curtindo e sei que cheguei em casa eram $4 \mathrm{~h}$ da manhã. Informante $\mathrm{E}$

$\mathrm{Na}$ infância, eu e duas amigas fazíamos um concurso de quem dublava melhor. No medley do "Beijo é Bom/Etc... E Tal/Vai Ter Que Rebolar/Dig-Dig-Joy" foi uma coisa que veio direto. Mandei o vídeo pra nossa amiga no grupo justamente por isso e perguntei: "Ah, lembram disso?". Informante $\mathrm{N}$

Uma coisa que achei muito legal do show é que tinha uma senhorinha, acho que ela devia ter levado a neta. Eu estava cansada da viagem, mas queria curtir aquilo, e ela estava naquele pique. Informante $\mathrm{Q}$

Lipovetsky (2007) explica como o consumidor opta pela preferência da realização de desejos particulares, porque ele quer sua felicidade em primeiro lugar e mostra-se "cada vez mais em busca de prazeres renovados, de experiências sensitivas ou estéticas, comunicacionais ou lúdicas. Excitação e sensações é que são vendidas, e é experiência vivida que se compra" (LIPOVETSKY, 2007, p. 40). Dessa forma, o prazer da experiência define o comportamento do atual consumidor e este hiperconsumidor quer viver momentos fora do comum, desconectados com o real (LIPOVETSKY, 2007).

Cheguei pro meu chefe e falei: "Ó, dia 09/11 eu não vou poder vir na loja", ele: "Por quê? Como assim?", "É bate e volta", "Tá bom, o que eu vou falar pra você se já tem o ingresso e a passagem, então vai". Informante $\mathrm{Q}$

Eu sou professora e resolveram marcar feira de ciências pro dia 09 [de novembro e falei: "Cara, a minha vida acabou nesse momento", porque a feira acabava $12 \mathrm{~h}$, e eu já tinha que estar na fila pra passagem de som. Choveu o dia inteiro, saí voada da feira, morta, porque tinha acordado $6 \mathrm{~h}$ da manhã. Choramos o show inteiro, porque a gente sabia 
que ia ser o ultimo, e aproveitamos ao máximo. Fui na roda gigante, no stand da Globoplay. Informante $\mathrm{O}$

A passagem de Fortaleza pro Rio de Janeiro, faltando um mês, tava muito cara, mas eu disse: "Bom, que pena, kkkk, vamos ter que viajar". Eu também ia ser fiscal no ENEM no dia seguinte. Informante $\mathrm{K}$

Outro dado percebido durante as entrevistas refere-se à "narrativa, fragmentos dela ou alguma referência previamente conhecida" (PEREIRA, ROCHA e SICILIANO, 2015, p. 9). Foi apresentada uma imagem da dupla no palco alternative e perguntado se eles relembraram uma cena de algum momento da carreira e quais os significados:

Literalmente o "Acústico", mas num momento de reunião de irmãos: "A gente tá vivendo um momento que nunca esperamos na vida e estamos aqui sentados com o violãozinho igual a gente tava fazendo em 1989, só que lá era a família, aqui eram nossos fãs, mais de 100 mil pessoas". Informante $\mathrm{C}$

Foi total o "Acústico MTV", um de frente pro outro, tem um resgate aí. Quando entrei e vi esse palco pensei: "O que estão planejando? Será que uma bateria vai subir dali?" Ninguém entendeu, mas quando vi isso, falei: "Fecharam com chave de ouro!". Informante H

Finalmente, diante de questionamentos sobe o significado do show, os informantes revelaram, de forma evidente, as experiências de consumo e o último show como um espaço de revisitação e de ressignificação de memórias.

Ao mesmo tempo que entendi muito do que eles significam e significaram pra mim, os lugares que eles ocupam na minha história, quão atemporal eles são. Eles podem fazer uma turnê daqui a dois anos e a gente vai estar lá porque memórias boas sempre gostamos de rever, energiza! Informante $\mathrm{N}$

"Nossa História" mudou a minha história porque eu perdi minha mãe em fevereiro de 2019, e no dia 13/03 anunciou a turnê. Ela sabia que eu precisava disso, então senti muito a presença dela. Informante $\mathrm{E}$

A turnê "Nossa História" me fez lembrar de quando fui diagnosticado aos dois anos com sopro no coração, e o médico falava que eu precisava fazer exercício, porque senão eu teria que fazer uma operação arriscada. Toda vez que lembrava disso, botava um CD deles e dançava pra ver se conseguia superar aquilo, tanto que aprendi a coreografia na marra, pra buscar mais saúde. Informante $C$

Quando soltam os fogos, parece até Ano Novo, a emoção, aquela sensação de alívio e de satisfação por ter participado e conseguido concretizar um sonho que você tem desde a infância. Informante I

Quando eu era criança, fui a shows da dupla, mas queria viver isso com um pouco mais experiência. Eu tô zero na vida! Informante $\mathrm{K}$ 
Pra mim é retornar a boas memórias que eu tive com eles durante 22 anos. Meu tio tinha uma frase clássica: "Quanto vale esse momento? Ele não tem preço!" É muito isso, tudo o que a gente se permitiu viver na turnê, no último show, todos os perrengues que passamos. Eu acho que não é dinheiro que pague estar ali vivendo aquilo porque vai ser "inesquecível em mim" como eles cantam, né? Informante $O$

\section{Considerações finais}

Com base nas falas analisadas até aqui, a busca por conforto e satisfação pessoal, a liberdade e a experiência única são alguns fatores que levam os fãs millennials a esses shows de celebração da carreira de um artista em específico. Como é uma geração que não depende mais financeiramente dos responsáveis, o comportamento dos fãs ficou refletido na alta compra de ingressos e na prioridade em consegui-los de alguma maneira e, ao mesmo tempo, revelaram o valor de uma marca que, mesmo após 12 anos sem atividades, conseguiu ser ressignificada. O consumidor millennial tem o poder de compra aumentado e está disposto a viver e reviver diversas experiências a qualquer preço.

Espaços imersivos que abrangem gatilhos nostálgicos só amplificam a intensidade do engajamento, não apenas pelo fã ali presente para revisitar a história da dupla, mas também por interpretar o significado da celebração de memórias. Todo conjunto de experiências do consumidor, mesmo antes da compra dos ingressos, gera valores. Portanto, conclui-se que partindo do olhar sobre o último show da "Nossa História" como um espaço que permite as experiências de consumo e o consumo de experiências, o evento não precisa ser considerado apenas como um produto, mas é muito mais que isso. É possibilitar a importância do resgate da memória em tempos rápidos, frágeis e confusos.

\section{Referências bibliográficas}

ALVES, Heitor de Lima. O significado cultural do consumo de música popular ao vivo (show) a partir da experiência vivenciada pelo consumidor. Recife: UFPE, 2017.

BELCZAK, Maria Eugênia. Grupo Focal. In: DUARTE, Jorge; BARROS, Antonio (Org.). Métodos e técnicas de pesquisa em Comunicação. 2a edição. São Paulo: Atlas, 2006. BORGES, Felipe; LAGE, Igor; LEAL, Bruno Souza. Experiências de nostalgia: de StrangerThings a Vozes de Tchernóbil, diferentes construções nostalgizantes. In: FERRAZ, Talitha; SANTA CRUZ, Lucia (Org.). Nostalgias e mídia: no caleidoscópio do tempo. $1^{\text {a }}$ edição. Rio de Janeiro: E-papers, 2018. 
BOTELHO, Delane;PLUTARCO; Flávia. A Volta dos Velhos e Bons Tempos: Proposições sobre o Construto Nostalgia na Área de Comportamento do Consumidor. XXXVI Encontro ANPAD, Rio de Janeiro, p. 1-13, set./2012.

COSTA, Alessandra de Sá Mello da; MELLO, Flávia Barroso de; PESSÔA, Luís Alexandre Grubits de Paula. Inovação e nostalgia no discurso publicitário brasileiro. Cadernos de Gestão e Empreendedorismo - UFF, v.5, n.3, p. 62-72, set-dez./2017.

CRUZ, Elena Cristina Pinto. A nova velha juventude: modernidade, mudança social e questões geracionais nas representações dos millennials. Rio de Janeiro: PUC-Rio, 2018.

FERRAZ, Talitha; SANTA CRUZ, Lucia. A propósito da nostalgia. In: FERRAZ, Talitha; SANTA CRUZ, Lucia (Org.). Nostalgias e mídia: no caleidoscópio do tempo. $1^{a}$ edição. Rio de Janeiro: E-papers, 2018.

HUYSSEN, Andreas. Seduzidos pela Memória: Arquitetura, Monumentos e Mídia. Rio de Janeiro: Editora Aeroplano, 2000.

KOTLER, Philip. Marketing 3.0. Ana Beatriz Rodrigues (Trad.). Rio de Janeiro:

Elsevier, 2010.

KOTLER, Philip; ARMSTRONG, Gary. Princípios de Marketing. Sabrina Cairo (Trad.) 15a edição. São Paulo: Pearson Education do Brasil, 2015.

LIPOVETSKY, Gilles. Os tempos hipermodernos. Mário Vilela (Trad.). São Paulo: Editora Bacarolla, 2004.

LIPOVETSKY, Gilles. A felicidade paradoxal: ensaio sobre a sociedade do hiperconsumo. Maria Lucia Machado (Trad.). São Paulo: Companhia das Letras, 2007.

LOPES, Francisca Flávia Plutarco. Apelo nostálgico no produto e na mensagem e sua influência na resposta do consumidor. São Paulo: Fundação Getúlio Vargas - Escola de Administração de Empresas de São Paulo, 2015.

MCCRACKEN, Grant. Cultura e Consumo: Uma Explicação Teórica da Estrutura e do Movimento do Significado Cultural dos Bens de Consumo. ERA - Revista de Administração de Empresas, v.47, n.1, Harvard Business School, p. 99-115, jan-mar./2007.

MORAIS, Adolfo. Marketing Cultural e Branding: análise da turnê do breve retorno da dupla Sandy e Junior. Centro Internacional de Semiótica e Comunicação - CISECO, VIII Colóquio Semiótica das Mídias - Alagoas, p. 1-16, nov./2019.

MORAIS, Alline; GOMES, Karen. Design Retrô e Marketing do Saudosismo: Influência da Tendência Nostálgica no Comportamento de Consumo. Revista Vértices, v.17, p. 215-233, setdez./2015.

NIEMEYER, Katherina. O poder da nostalgia: Sobre o papel e o lugar da mídia e da comunicação (acadêmicos) em estudos sobre nostalgia. In: FERRAZ, Talitha; SANTA CRUZ, Lucia (Org.). Nostalgias e mídia: no caleidoscópio do tempo. $1^{\text {a }}$ edição. Rio de Janeiro: Epapers, 2018. 
PEREIRA, Cláudia; SICILIANO, Tatiana; ROCHA, Everardo. "Consumo de Experiência" e "Experiência de Consumo": Uma Discussão Conceitual. Revista LOGOS 43 - Dossiê: Cotidiano e Experiência, v.22, n.2, Rio de Janeiro, p. 6-17, $2^{\circ}$ semestre de 2015.

PEREZ, Clotilde.Há limites para o consumo? Lucia Santaella (coord.). $1^{\text {a }}$ edição. Barueri, São Paulo: Estação das Letras e Cores, 2020.

SANTA CRUZ, Lucia. O passado está de volta: a produção e o consumo da nostalgia na Economia Criativa. IX Encontro Nacional de Estudos do Consumo. ESPM: Rio de Janeiro, p. 119, nov./2018. 